\title{
睡眠時無呼吸症候群における上気道内径の測定
}

\author{
大谷 信 夫
}

\section{Pharyngeal Cross-sectional Area in Sleep Apnea Syndrome}

Nobuo Ohya, M.D.

Division of Respiratory Disease, Department of Internal Medicine,

Kanazawa Medical University, Ishikawa

\begin{abstract}
Acoustic reflection technique (AR) was applied to evaluate the pharyngeal space and its behavior responding to various stresses in obese patients and patients with obstructive sleep apnea (OSA). Pharyngeal space was narrower and its wall was more compliant in obese patients and patients with OSA than those of control patients. Whether the patient is obese or not, it is an important finding of AR that the pharyngeal wall of patients with OSA was more compliant than that without OSA. This fact was observed in the following conditions; natural breathing, pressure load in the upper airway during natural breathing, positional change of the body. AR is a non-invasive and useful tool to evaluate the role of pharyngeal space in sleep apnea.
\end{abstract}

Key words : obstructive sleep apnea, acoustic reflection technique, pharyngeal cross-sectional area, pharyngeal compliance, obesity

\section{はじめに}

睡眠時無呼吸症候群（以下 SAS）には，胸郭 の呼吸運動の停止を伴う中枢型 (以下 CSA) と, 呼吸運動は存続しているが上気道の閉塞による 気流停止を来たす閉塞型(以下 OSA) とがある。 両型の混在するもの, OSA から CSA に移行す る例もあり, 両型の間の病態生理学的機序につ いては論議がある ${ }^{1,2)} 。$ 一般には「無呼吸」その ものの生体に及ぼす影響を重視して両型を一括 しSAS と称するが, 本稿に与えられたテーマ はOOSA を中心に扱うことになるのをお断りし

金沢医科大学呼吸器内科

別刷請求： $=$ 920-02 石川県河北郡内灘町大学1-1 金沢医科大学呼吸器内科 大谷信夫

投稿受付: 1989 年 5 月 10 日
たい。

OSAの上気道の観察にはX X 線学的方法と内 視鏡的方法が一般的である。前者にあっては単 純写真や断層写真も利用できるが, 半定量的判 断に止まることや，ダイナミックな変化，睡眠 と覚醒時の差異について検索しがたい欠点があ る。CT像を利用すれば狭窄部位も断面積の定 量化も可能であり ${ }^{3)}$, cine CT を利用できれば睡 眠と覚醒時の比較もできるし，ダイナミックな 変化も観察しうる4。

図 1 はCT 所見より得られた覚醒時仰臥位に おける上気道断面積を示している。上図の正常 者群は最も狭い部位でも $1 \mathrm{~cm}^{2}$ 以上であるが, 下図の OSA 群は $1 \mathrm{~cm}^{2}$ 以下を示す部位が咽頭 のどこかに必ず存在する。この上気道が体位と か睡眠とかでどのように変化するかは CT の限 


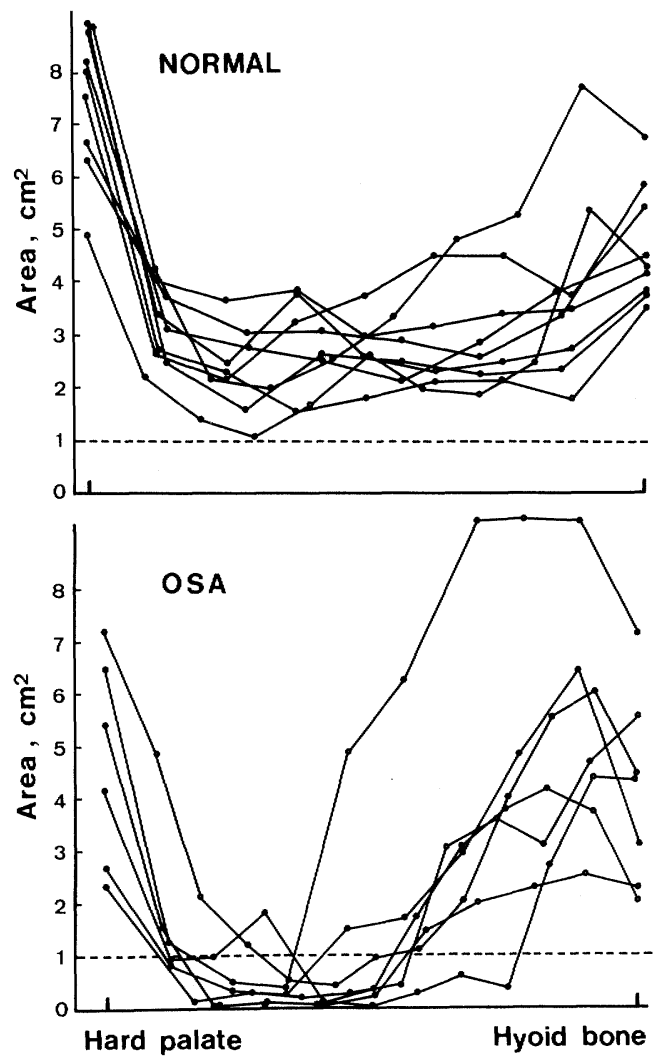

図 1 CT 所見による上気道断面積

健常者 (normal) と閉塞型睡眠時無呼吸患者 (OSA) の比較

界を超えており， cine CT の所見が期待される が，まだ一般的に使用されていないし，visual で あっても定量的表現には困難を伴う。

内視鏡は一般的に使用可能であり, 覚醒時と 睡眠時（なぜか SAS 患者は内視鏡を挿入した ままで入眠する人が多い) の比較，狭窄部の同 定と程度, 狭窄の原因, 狭窄部のダイナミック な変化をも観察できる利点がある。しかし，患 者の苦痛を伴うことも事実であり, 定量的な判 定をするには困難がある。

最近，パルス音波を用いた測定法（acoustic reflection technique, AR と略す) が Jackson ら ${ }^{5}$ によって開発され，臨床的に広く応用され るに至っている。本法は非侵襲的で短時間で上 気道の断面積を推定でき, 呼吸相や体位による ダイナミックな変化を，また，装置を工夫すれ
ば上気道壁の腔内圧に対する振舞いをも観察す ることができる。われわれもこのシステムを試 作し, いくつかの点をチェックしつつ ${ }^{6 \sim 8)} \mathrm{OSA}$ を中心に SASの上気道の観察を行ったので， 以下 AR の所見について述べてみたい。

\section{I . AR の原理と装置}

図 2 は AR の原理を示す。今, 図 2 に示した 剛管の左端よりパルス音波を入射し，トランス ジューサーより $\mathrm{X}_{0}$ の点に管の断面積の変化が あったとする。この点で音波は反射波と透過波 に分かれ，管腔の変化が大なるほど反射波は強 く返ってくる。観測点トランスジューサーでは 入射波と反射波の時間差から $\mathrm{X}_{0}$ という距離を 算出し，反射波の強さから断面積を推定する。

図 3 は現在われわれが使用している AR 装 置の概要である。被検者は内径 $1.6 \mathrm{~cm}$, 長さ 4 $\mathrm{m}$ のウェーブチューブをロにくわえている。な お，チューブの被検者側には体位を変えても測 定可能なように弯曲チューブでの測定も可能な ことを確かめてある9 。中央のホーンドライバ 一からパルス音波を発射し，気道内からの反射 波を口から $30 \mathrm{~cm}$ 離れたチューブの部位に接続 されたトランスジューサーで観察し，断面積一 距離関数をWare-Akiのアルゴリズム ${ }^{10)}$ を用 いて算出する。ウェーブチューブの対側末端に は，スパイロメーターを接続し換気量を測定, また，測定中に抵抗負荷をかけて上気道腔内圧 に対する気道壁（ここでは咽頭壁）の反応をみ るときは压力トランスジューサーで圧測定も可 能である。

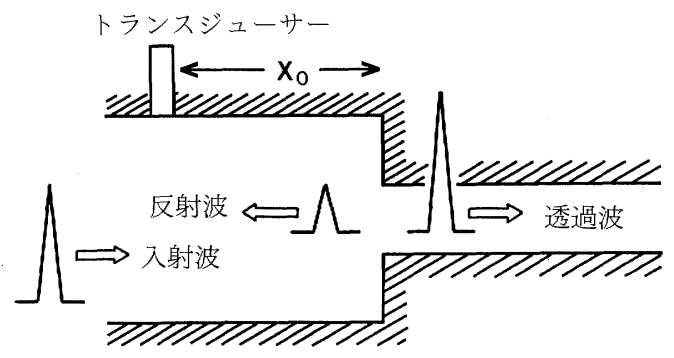

図 2 Acoustic reflection technique (AR) の原理 
日気食会報，40（5)，1989

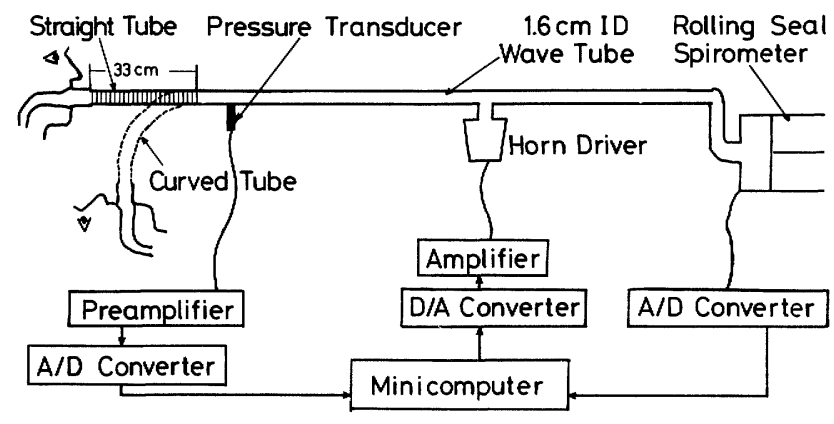

図３ＡR 装置のブロックダイアグラム

図 4 は破線で示す断面積をもつ剛管モデルを 本装置で測定（実線）したものであり，ほ汴満 足すべき結果である。今, 必要とする上気道は しかし弾性管とみなすべきである。Fredberg ら ${ }^{11)}$ は, $\mathrm{He}-\mathrm{O}_{2}$ ガスを用いることによって気道 の断面積がより正確に測定できることを示し た。

図 5 は上段の管腔モデルの破線部を剛管また は弾性管とし，それぞれ air と $\mathrm{He}^{-} \mathrm{O}_{2}$ ガスで測 定した結果である。明らかに弾性管においては $\mathrm{He}^{-} \mathrm{O}_{2}$ の方が精度は air に比し良好である。

しかしながら，図 6 に示すように気管(右図) はさておき，咽頭（左図）に関してはairと $\mathrm{He}^{-}$ $\mathrm{O}_{2}$ 測定值の一致率は非常に良好である。検查の 手技上も airの方がいろいろな面で有利である ので, SASに関する限り測定には air 呼吸で十 分であると考えられる。

図 7 は実際の測定例である。横軸距離は $\mathrm{O}$ 点 を門歯として描いてある。声門部は比較的容易

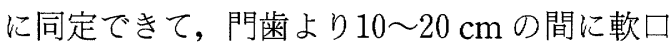
蓋〜咽頭が位置している。SAS ではこの部位が 各種の状況でどのように振舞うかが観察の要点 となる。

\section{II . SAS とARによる気道内径測定}

肥満者にOSA が多いのは周知の事実であ る。図 8 は正常者と肥満者の比較の実測例を示 す。明らかに咽頭部は肥満者では狭い。OSA 7 名を含む男子肥満者 14 名と健康男子 10 名を比較 すると，咽頭最狭小部断面積 (minimum area) も咽頭平均断面積（average area）も肥満者は

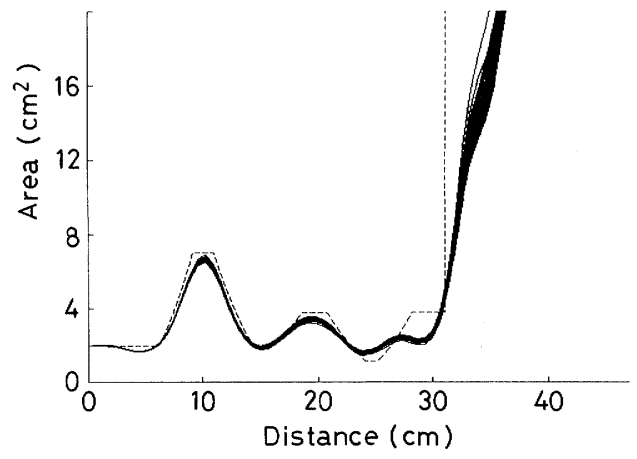

図4モデル(剛管)におけるAR測定の妥当性検討

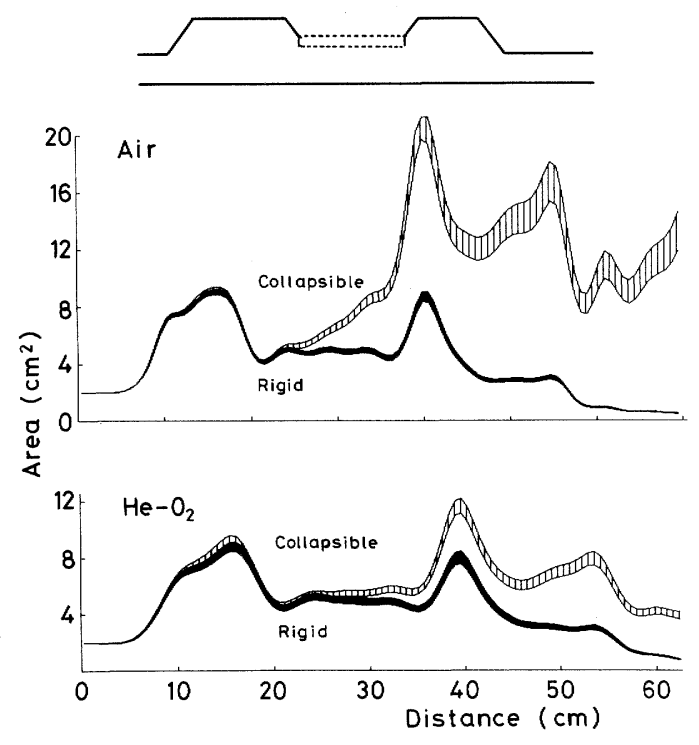

図 5 モデルにおける AR 測定の妥当性検討 (剛管と弾性管との比較) 

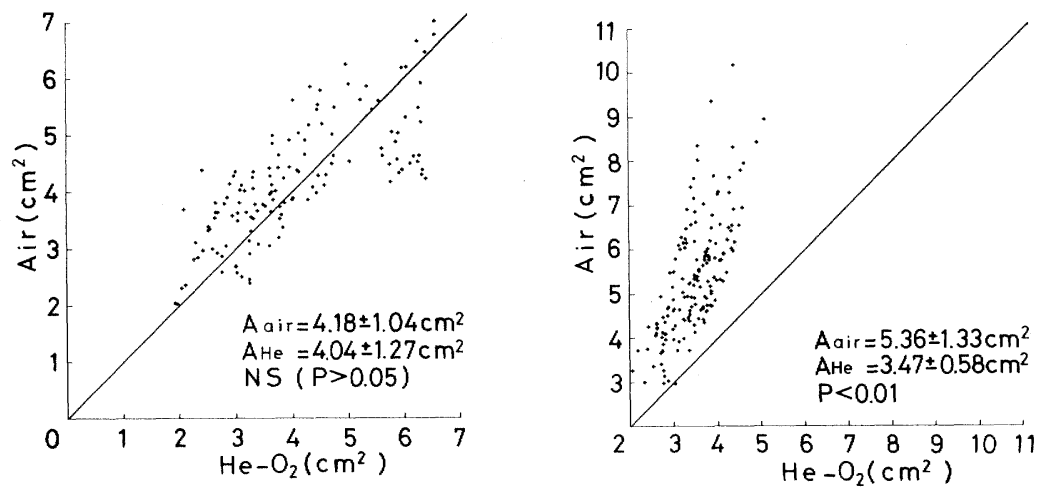

図 $6 \mathrm{AR}$ による咽頭腔・気管断面積の測定

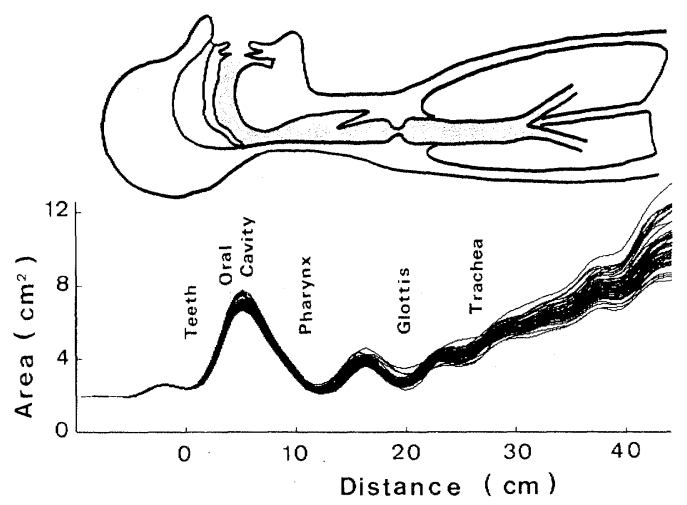

図 $7 \mathrm{AR}$ による実測例

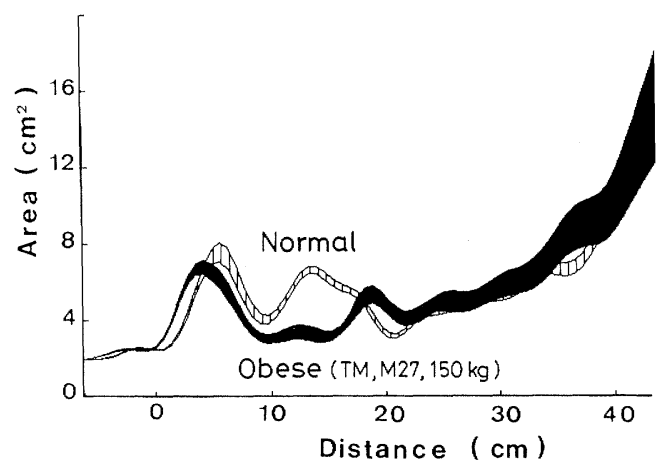

図 8 健常者と肥満者の咽頭腔の比較 (実測)
それぞれ $2.81 \mathrm{~cm}^{2}, 3.62 \mathrm{~cm}^{2}$ で，正常者のそれ は $4.20 \mathrm{~cm}^{2}$ と $4.71 \mathrm{~cm}^{2}$ であった（図 9 )。

一方, 肥満者の中では OSA と非 OSA では有

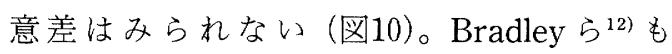
OSA, 非 OSA にかかわらず，いびきをかく者は いびきをかかない者に比して咽頭腔は狭く, OSA と非 OSA の差は肺気量を低下させると， 咽喉腔はOSA 群ではより狭くなることである といい, OSAにおける咽頭の役割は単に狭いだ けでは説明がつかないことを指摘している。咽 頭腔の狭小化が肺気量の低下に従って強調され るとの報告は他にいくつか見られる ${ }^{13,14)}$ 。

一方，咽頭の狭小ばかりでなく，咽頭の壁の 振舞いに注目する研究は Hoffstein一派によっ てすすめられている。彼らはあらかじめ定めた 肺気量位で, 咽頭腔内に圧をかけたときの咽喉 の振舞いを AR で観測した。いびきをかく人で も OSA は咽頭壁のコンプライアンスは大とな っており ${ }^{15)}$ ，しかも坐位から臥位になると OSA 患者の咽頭は著明に compliant になる ${ }^{16)} 。$

図11は肥満者で OSA を有するものの方が呼 吸による咽頭腔の変化が大きくなることを示し ている。図12は呼吸中に抵抗負荷をかけて咽頭 内圧を, 呼気にはより陽性に, 吸気にはより陰 性になるようにして記録したものであるが，下 図の OSA の咽頭腔断面積の変化がより大き い。図11, 12はいずれも, Hoffstein一派の OSA では咽頭壁がより compliantになっていると の見解を支持するものである。図13は体位によ 
日気食会報，40（5）, 1989
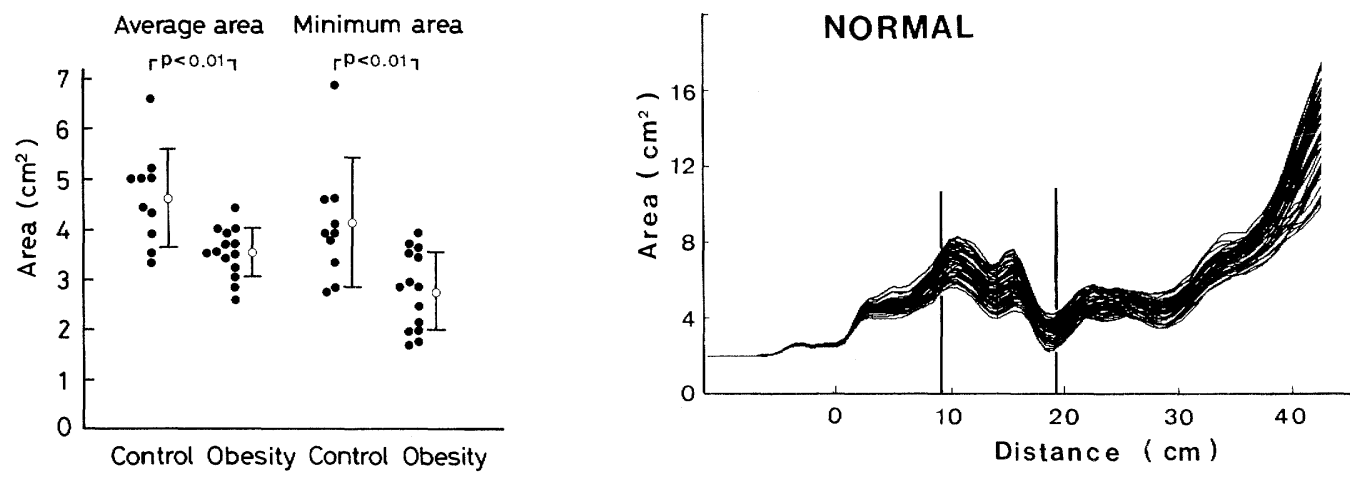

図 9 健常者と肥満者の咽頭腔の比較

肥満者の咽頭腔は平均断面積（average area）でも 最狭小部断面積（minimum area）でも狭い。

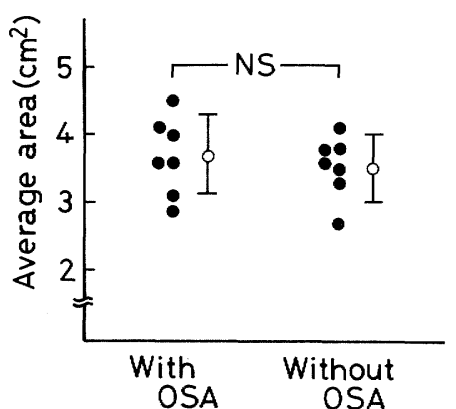

図10 肥満者での OSA と非 OSA に扔ける咽頭断 面積

A. With OSA (KM M3O)
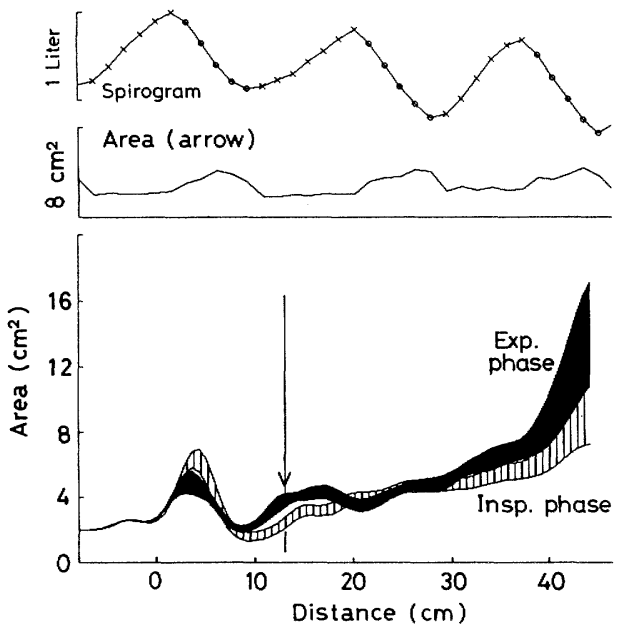

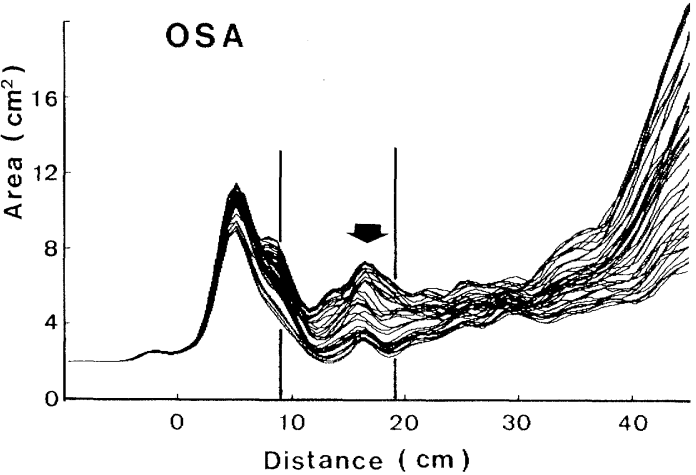

図12 咽頭腔のコンプライアンス

呼吸時に圧負荷をかけるとOSA では咽頭腔の変化 は大きい。

B. Without OSA (TA M28)
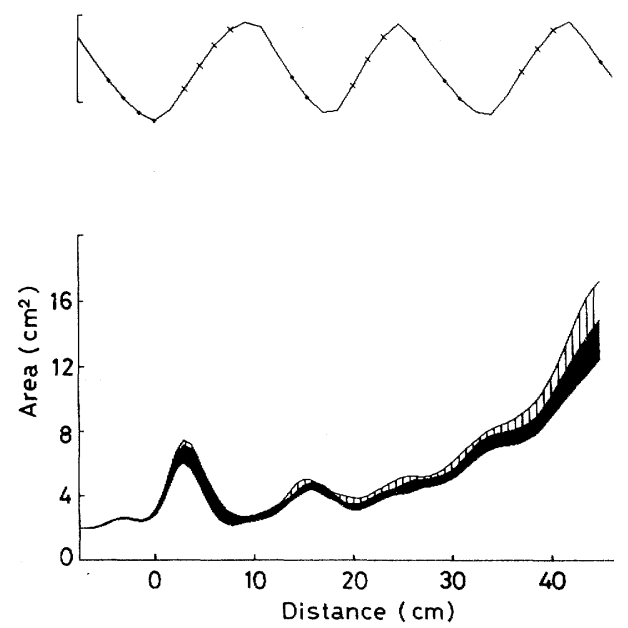

図11 呼吸運動と咽頭断面積の変化

OSA 患者は呼吸による変化は大きい。 


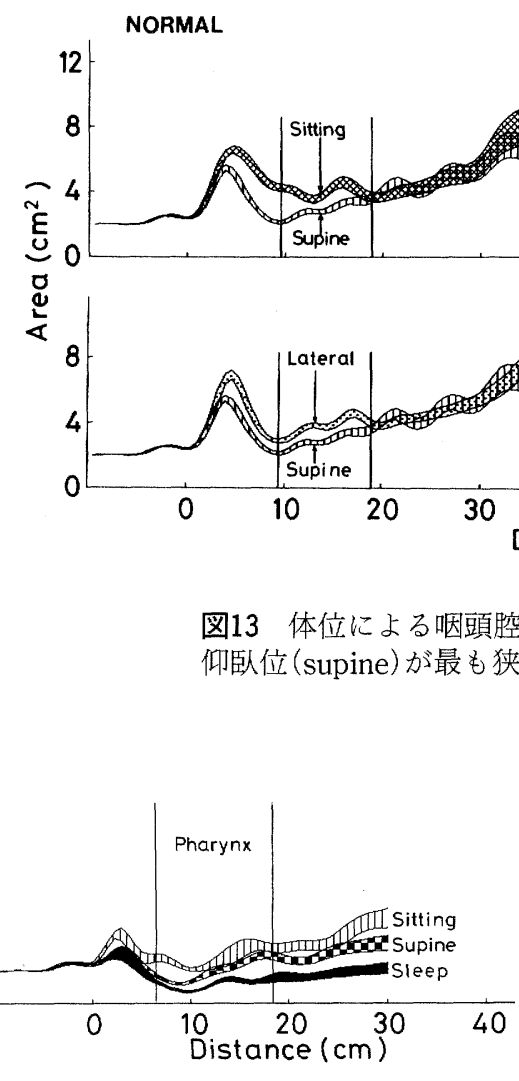

図14 睡眠による咽頭腔の変化

る咽頭腔の変化を示す。いずれも坐位, 側臥位, 仰臥位の順に咽頭腔は狭くなるが, OSA ではそ の変化の度合いが大きいことが示される。

Hudgel ${ }^{17)}$ は, 上気道内圧を数か所測定して 覚醒時の観察で睡眠時の閉塞部位を予想するの は困難であると述べている。図14は睡眠中にも AR で観察しえた 1 例である。坐位に比して仰 臥位では咽頭腔は狭くなり，この位置で睡眠を するとさらに狭くなる様子がよくとらえられて いる。

以上のようにOSAにおいては, 咽頭腔は単 に狭いだけでなく，咽頭壁のダイナミックな振 舞いにも特色があることが判明したのは AR の導入によるところが大きい。注目すべき点は, CSAにおいても咽頭腔の肺気量依存性は大き く，かつコンプライアンスは大であるとの報告 があることである ${ }^{18)}$ 。また,このような咽頭の振
舞いには咽頭部の奇異性吸気狭窄 ${ }^{19)}$ が関与す るという報告がある。この領域も ARの観察が 可能な領域であるから，ARの有用性は形態面 にも機能面にも利用され, 今後新しい知見を提 供することになろうと期待される。

現在, OSA の治療として nasal CPAP, 気管 切開, uvulopalatopharyngoplastyなどが行わ れているが，その治療効果を予見することは必 ずしも容易ではない。最近，顔面の骨格異常と 咽頭の狭小化にも相関がみられている ${ }^{20)}$ 。OSA 患者の咽頭腔の形態と機能は, 治療上からも鼻 咽腔や喉頭, 顔面骨格, 肥満など多方面からの 関連においての観察が必要である。AR は要求 のすべてを満足するものではないが, 有力な検 查方法として臨床に利用される可能性があるも のとしてここに紹介した次第である。

\section{文献}

1) Cherniak, N.S., Longobardo, G.S., Gothe, B., et al.: Interactive effects of central and occlussive apnea. Adv. Physiol. Sci., 10:553$560,1981$.

2) Issa, F.G., and Sullivan, C.E. : Reversal of central apnea using nasal CPAP. Chest, 90 : 165-171, 1986.

3 ) Suratt, P.M., Richard, P.D., Atkinson, R.L., et al.: Fluoroscopic and computed tomographic features of the pharyngeal airway in obstructive sleep apnea. Am. Rev. Respir. Dis., 127: 487-492, 1983. 
4 ) Stein, M.G., Gamsu, G., de Geer, G., et al. Cine CT in obstructive sleep apnea. Am. J. Radiol., 148 : 1069-1074, 1987.

5 ) Jackson, A.C., Butler, J.P., Millet, E.J., et al. : Airway geometry by analysis of acoustic pulse response measurements. J. Appl. Physiol., 43 : 523-536, 1977.

6 ）黄正寿, 沈海, 大谷信夫：パルス音波を用いた 気道断面積測定法. 第 2 回生体・生理工学シン ポジウム, pp.85-88, 1987.

7 ）野口哲彦, 北川駿介, 大谷信夫・他：パルス音 波を用いた肥満者の上気道断面積測定につい て. Ther. Res., $7: 867-873,1987$.

8 ）沈海, 北川駿介, 大谷信夫・他：パルス音波を 用いた気道断面積測定法一空気呼吸とへリウム 酸素混合ガス呼吸の比較. Ther. Res., 8： 1294-1299, 1988.

9 ）沈海，北川駿介，大谷信夫・他：パルス音波を 用いた上気道断面積測定一体位による変化。日 胸疾会誌，27(増刊号)：329, 1989.

10) Ware, J.A., and Aki, K.: Continuous and discrete inverse scattering problems in a stratified elastic medium. I. Plane waves at normal incidence. J. Acoust. Soc. Am., 54 : 911-921, 1969.

11) Fredberg, J.J., Wohl, M.B., Glass, G.M., et al. Airway area by acoustic reflections measured at the mouth. J. Appl. Physiol., 48: 749-758, 1980.

12) Bradley, T.D., Brown, I.G., Grossman, R.F., et al.: Pharyngeal size in snorers, nonsnorers, and patients with obstructive sleep apnea. New Engl. J. Med., 315 : 1327-1331, 1986.

13) Hoffstein, V., Zamel, N., and Phillipson, E.A. : Lung volume dependence of pharyngeal crosssectional area in patient with obstructive sleep apnea. Am. Rev. Respir. Dis., 130 : 175178, 1984.

14) Brown, I.G., Zamel, N., and Hoffstein, V.: Pharyngeal cross-sectional area in normal men and women. J. Appl. Physiol., 61:890$895,1986$.

15) Brown, I.G., Bradley, T.D., Phillipson, E.A., et al.: Pharyngeal compliance in snoring subjects with or without obstructive sleep apnea. Am. Rev. Respir. Dis., 132 : 211-215, 1985.

16) Brown, I.G., Mcclean, P.A., Boucher, R., et al.: Changes in pharyngeal cross-sectional area with posture and application of continuous positive airway pressure in patients with obstructive sleep apnea. Am. Rev. Respir. Dis., 136 : 626-632, 1987.

17) Hudgel, D.W.: Variable site of airway narrowing among obstructive sleep apnea patients. J. Appl. Physiol., 61 : 1403-1409, 1986.

18) Bradley, T.D., Brown, I.G., Zamel, N., et al. : Differences in pharyngeal properties between snorers with predominantly central sleep apnea and those without sleep apnea. Am. Rev. Respir. Dis., 135：387-391, 1987.

19) Rubinstein, I., Colapinto, N., Rotstein, L.E., et al. : Improvement in upper airway function after weight loss in patient with obstructive sleep apnea. Am. Rev. Respir. Dis., 138：1192 1195, 1988.

20) Partinen, M., Guilleminault, C., Quera-Salva, M.A., et al.: Obstructive sleep apnea and cephalometric roentgenograms. The role of anatomic upper airway abnormalities in the definition of abnormal breathing during sleep. Chest, $93: 1199-1205,1988$. 